\title{
Padronização do potencial evocado auditivo de tronco encefálico utilizando um novo equipamento*****
}

\author{
Standardization of brainstem auditory evoked potential using a new \\ device
}

\begin{abstract}
Ilka do Amaral Soares*
Pedro de Lemos Menezes**

Aline Tenório Lins Carnaúba***

Liliane Desgualdo Pereira****
\end{abstract}

*Fonoaudióloga. Mestre em Ciências pelo Departamento de Fonoaudiologia da Universidade Federal de São Paulo (Unifesp). Professora Auxiliar da Universidade Estadual de Ciências da Saúde de Alagoas. Endereço para correspondência: R. Dr. Antonio Cansanção, 55 Apto. 703 - Maceió - AL - CEP 57035-190

(ilkaamaralsoares@gmail.com).

**Fonoaudiólogo. Doutor em Física Aplicada à Medicina e Biologia pela Universidade de São Paulo (USP). Professor Adjunto da Universidade Estadual de Ciências da Saúde de Alagoas.

***Fonoaudióloga. Especializanda em Audiologia Clínica pela Faculdade Integrada Tiradentes.

****Fonoaudióloga. Livre-Docente pela Unifesp. Professora Associada do Departamento de Fonoaudiologia da Unifesp.

*****Parte de Dissertação de Mestrado do Programa de Pós-Graduação em Distúrbios da Comunicação Humana da Unifesp, Realizado na Faculdade de

Fonoaudiologia de Alagoas da Universidade Estadual de Ciências da Saúde de Alagoas.

Artigo Original de Pesquisa

Artigo Submetido a Avaliação por Pares

Conflito de Interesse: não

Recebido em 27.05.2010

Revisado em 06.09.2010; 12.11.2010;

19.11.2010; 23.11.2010.

Aceito para Publicação em 23.11.2010.

\begin{abstract}
Background: standardization of Brainstem Auditory Evoked Potential (BAEP) using a new device. Aim: to standardize BAEP responses using a new device developed (NDD) in Brazil. Method: analysis of absolute latencies, interpeaks and wave amplitudes of BAEP, using a new device developed to study normal-hearing groups (91 adults) and individuals (15 adults) with bilateral neurosensory hearing loss. Responses obtained in the EP15 hearing device/Interacoustics and the NDD were compared. For this, the following paramenters were used: non-filtered click of 100 microsecond ( $\mu$ s), totaling 2000 stimuli in rarefied polarity, stimulation frequency of 13.1 clicks/s, intensity of 80 decibels normalized hearing level (dB nHL), with a window of 10 milliseconds and bandpass filter between 100 and $3000 \mathrm{Hertz}(\mathrm{Hz})$. Significance level was set at 0.05 . Results: absolute latency and interpeak means for 76 normal-hearing individuals with the NDD were: wave $\mathrm{I}=1.50, \mathrm{III}=3.57, \mathrm{~V}=5.53, \mathrm{I}-\mathrm{III}=2.06, \mathrm{III}-\mathrm{V}=1.96$ and $\mathrm{I}-\mathrm{V}=4.02$. When analyzing results according to gender, there was a statistically significant difference for the absolute latencies of waves III and V and in interpeaks I-III and I-V. Mean amplitude value of wave $\mathrm{I}=0.384$ microvolt $(\mu \mathrm{V})$ and of wave $\mathrm{V}=0.825 \mu \mathrm{V}$. There was no statistically significant difference between the absolute latencies and interpeaks of the two devices in the same individual. Conclusion: the components of BAEP with the NDD in normal-hearing subjects were similar regarding the tested ears, with statistically lower latencies in women. The BAEP latencies in the same individual with NDD were similar to those obtained with the EP15 / Interacoustics. Normal values of BAEP were obtained in normal-hearing adults.
\end{abstract}

Key Words: Evoked Potentials; Adult; Hearing Loss.

\section{Resumo}

Tema: padronização do Potencial Evocado Auditivo de Tronco Encefálico (PEATE) utilizando um novo equipamento. Objetivo: padronizar as respostas do PEATE utilizando de um novo equipamento desenvolvido (NED) no Brasil. Métodos: análise das latências absolutas, interpicos e das amplitudes das ondas do PEATE, por meio de um novo equipamento desenvolvido para estudar grupos de ouvintes normais (91 adultos) e outro com perda neurossensorial (15 adultos) com perda auditiva neurossensorial bilateral entre o equipamento EP15 / Interacoustis e o NED. Utilizando o clique não filtrado, com duração de 100 microssegundo ( $\mu$ s), totalizando 2.000 estímulos, na polaridade rarefeita, frequência de estimulação de 13,1 cliques/s, intensidade de 80 decibels de nível de audição normalizado (dB NAn), com janela de 10 milissegundos e filtro passa-banda entre 100 e 3000 Hertz (Hz). Nível de significância de 0,05. Resultados: as médias das latências absolutas e interpicos em 76 ouvintes normais no NED foram: onda $I=1,50$, $\mathrm{III}=3,57, \mathrm{~V}=5,53$, I-III=2,06, III-V=1,96 e I-V=4,02. Ao separar por gênero houve diferença estatisticamente significante para as latências absolutas das ondas III e V e nos interpicos I-III e I-V. Valor médio da amplitude da onda $\mathrm{I}=0,384$ microvolt $(\mu \mathrm{V})$ e da onda $\mathrm{V}=0,825 \mu \mathrm{V}$. Não existiu diferença estatisticamente significante ao comparar as latências absolutas e interpicos entre dois equipamentos no mesmo indivíduo. Conclusão: os componentes do PEATE com o NED em ouvintes normais foram similares quanto às orelhas, com latências menores estatisticamente significantes nas mulheres. As latências do PEATE no mesmo indivíduo com o NED foram semelhantes às obtidas com o EP15 / Interacoustis. Foram obtidos os valores de normalidade para o PEATE em adultos ouvintes normais.

Palavras-Chave: Potenciais Evocados Auditivos do Tronco Encefálico; Respostas Evocadas Auditivas do Tronco Encefálico; Perda auditiva.

Referenciar este material como:

1 Soares IA, Menezes PL, Carnaúba ATL, Pereira LD. Standardization of brainstem auditory evoked potential using a new device (original title: Padronização do potencial evocado auditivo de tronco encefálico utilizando um novo equipamento). Pró-Fono Revista de Atualização Científica. 2010 out-dez;22(4):421-6. 


\section{Introduction}

Auditory evoked potentials (AEP) are a record of electrical activity that occurs in the auditory system along the auditory pathway, from the inner ear to the cerebral cortex, in response to an acoustic stimulus(1).

The most widely used method is brainstem evoked auditory potential (BAEP), due to its reproducibility and facility in detecting lesion sites. It evaluates auditory pathway integrity from the auditory nerve to the brainstem for 8 milliseconds (ms) after stimulus(2).

The BAEP results obtained are interpreted by using the time spent between the sound stimulus offered and the emergence of five positive deflections, namely waves I, II, III, IV and V and the interval between them, denominated absolute latencies and interpeak latencies(3,4).

An electronic device composed of a computer, acoustic signal generator, amplifier and register is used to perform the examination. Responses take place after sound stimulation, presented through ear phones or bone vibrators(5).

The devices available on the market to conduct this examination are expensive, in addition to having parameter configuration limitations. To minimize these problems, Menezes(6), in his doctoral thesis, defended at the University of São Paulo, developed a device to analyze AEP. Hypothesis: The results of brainstem evoked auditory potentials (BAEP) in the new device (ND) are similar to those obtained with the Interacoustics EP15, widely used in audiology clinical practice. Aim: Standardize BAEP responses using a new device developed in Brazil.

\section{Method}

The examinations were conducted at the Audiology Laboratory of the Faculty of Speech Therapy at the State University of Health Sciences of Alagoas (UNCISAL) and SINUS Clinic of Otolaryngology, both located in the city of Maceio, Brazil.

Calculations were made to assess the differences between the two diagnostic devices, using an alpha of 0.05 , a beta error of 0.1 , standard deviation of 0.1 ?V, and a minimum difference between the groups of 0.07 , which represents even greater accuracy than that obtained in research protocol calculations. The number estimated for the proposed study was 76 cases.

Thirty-five of the 76 normal hearers (70 ears) were males and 41 females (82 ears), aged between
18 and 49 years(6). Electrophysiological responses (absolute and interpeak latencies) of the 76 normal hearers (152 ears) belonging to experimental group 1 (EG1), using the new device (ND), were compared according to gender and ear. This was done to obtain the standard reference. To evaluate the object of study (auditory pathway integrity) using the ND, another group of 15 normal hearers (30 ears), consisting of six men and nine women, aged between 21 and 46 years, was formed. Brainstem evoked auditory potential (BAEP) was performed using the Interacoustic EP15 and ND. Responses obtained on the EP15 constituted Gold Group 1 (GG1) and those obtained from the same individuals on the ND constituted Experimental Group 2 (EG2).

To evaluate the sensitivity of the examination carried out with the new device, a group of 15 volunteers (8 men and 7 women), denominated Gold Group 2 (GG2), with bilateral sensorineural hearing loss (30 ears), auditory thresholds less than or equal to $60 \mathrm{dBNA}$, aged between 18 and 50 years, the same age range as previous groups, was selected for BAEP on the Interacoustic EP15. These same individuals, denominated Experimental Group 3 (EG3), underwent BAEP with the ND.

Thus, the sample consisted of 106 individuals, all residing in the city of Maceio, in the state of Alagoas, Brazil.

The group of normal hearers was composed of adults with normal audibility thresholds, that is, less than 25 dBNA at all pure tone audiometry frequencies, with interaural frequency differences less than or equal to $10 \mathrm{~dB}$.

The group with bilateral sensorineural auditory loss was formed by adults with altered audibility thresholds, that is, between 25 and 60 dBNA for frequencies from 2000 to $8000 \mathrm{~Hz}$ of pure tone audiometry. Thresholds of 250, 500 and $1000 \mathrm{~Hz}$ could be altered or not.

The stimulus was a non-filtered click of $100 \mu \mathrm{s}$ (total of 2000 stimuli) in negative (rarefied) polarity at a stimulation frequency of 13.1 clicks/s, intensity of 80 dBNAn for each ear in both devices in gold groups 1 and 2 and only in the ND in experimental groups 1,2 and 3 . The window of analysis was 10 ms and high-pass and low-pass filters of 100 and $3000 \mathrm{~Hz}$, respectively were used. Each measurement was performed in duplicate to ensure reproducibility and reliability of the waves.

The earth electrode was placed on the maxillary region and negative electrodes (A2 and A1), corresponding to the right ear (RE) and left ear (LE) respectively, were fixed to both mastoids. The positive electrode (Fpz) was fixed to the frontal lobe at the level of the sagittal plane, near the 
midline, in accordance with International System of Electrode Placement norms. A Beyerdynamic DT48 earphone was used.

The test measured absolute latency, in milliseconds (ms), of waves I, III and V, as well as interpeak latencies I-III, III-V and I-V for each ear and the amplitude of waves I and V.

The parameters most commonly used to evaluate auditory pathway integrity in adults using BAEP include: absolute latencies of waves I, III and $\mathrm{V}$, interaural difference of wave $\mathrm{V}$, the amplitude $\mathrm{V}$ to amplitude I ratio, and interpeak latencies I-III, III-V and I-V(7,8). These values must be known to interpret auditory pathway integrity(9).

Electrophysiological responses (absolute and interpeak latencies) in 30 ears from the other group of 15 normal hearers (experimental group 2) in the ND were compared with those obtained in the same individuals that formed gold group 1 using the traditional device, that is, the gold standard of the market. This was done to obtain specificity of the examination in the ND.

Electrophysiological responses (absolute and interpeak latencies) in 30 ears from the other group of 15 individuals with sensorineural hearing loss (experimental group 3) in the ND were compared with electrophysiological responses obtained in the same individuals using the traditional device (gold group 2). This was done to obtain sensitivity of the examination for sensorineural hearing losses in the ND. Thus, it was possible to determine the effectiveness of the electrophysiological examination using the new device.

The sample of data obtained in 76 normal hearing individuals (EG 1) with the new device was analyzed using descriptive statistics, considering gender and ear. The Kolmogorov-Smirnov test was used to analyze normality, the non-parametric Mann-Whitney to compare sexes and the Wilcoxon to compare ears. The significance level was set at 0.05 .

The paired Student's t-test, at a significance level of 0.05 , was used to compare data obtained in individuals who underwent the procedure (BAEP) on two devices (ND and EP15).
Since interpeak interval values do not exhibit normal distribution, the two devices were compared using the non-parametric Wilcoxon test.

Statistical Package for Social Sciences (SPSS) 17.0 software was used to obtain calculations.

\section{Results}

Table 1 shows the latency values of waves I, III and $\mathrm{V}$ and interpeak intervals of BAEP for gender and ear, calculated using Wilcoxon and Mann-Whitney U tests.

Data separated by gender reveal that normal hearing women have statistically significant lower BAEP latencies than men, with mean values of 3.53 in wave III, 5.48 in wave V, 2.04 in interpeak I-III and 3.99 in interpeak I-V in women and 3.61 in wave III, 5.59 in wave V,2.10 in interpeak I-III and 4.07 in interpeak I-V in men.

Amplitude results of waves I and $\mathrm{V}$ showed a mean value of $0.384 \mu \mathrm{V}$ for wave I and $0.825 \mu \mathrm{V}$ for wave $\mathrm{V}$. Tracings whose amplitudes for waves $\mathrm{V}$ and I showed a ratio of less than $1 \mu \mathrm{V}$ in three ears (8.10\%) and greater than $1 \mu \mathrm{V}$ in 34 ears $(91.90 \%)$.

Mean normality reference values and standard deviations obtained for BAEP in normal hearing adults are illustrated in table 2 . The following parameters were used for this measure: duration of $100 \mu \mathrm{s}$, stimulation frequency of 13.1 clicks/s, intensity of 80 dBNAn, in rarefied (negative) polarity for each ear.

The $\mathrm{V}$ to I ratio varied between 0.6 and $8.0 \mu \mathrm{V}$, but only $8.1 \%$ of the ears showed a ratio of less than one, whereas $91.9 \%$ of the ears had a ratio above one.

The p-value obtained using the non-parametric Wilcoxon statistical test showed no significant differences between the two devices, for normal hearers and individuals with sensorineural hearing loss. The pvalues found for normal hearers were: waves $\mathrm{I}=0.980$, $\mathrm{III}=0.580, \mathrm{~V}=0.424$, interpeaks $\mathrm{I}-\mathrm{III}=0.871, \mathrm{III}-\mathrm{V}=0.057$ and $\mathrm{V}-\mathrm{I}=0.147$. The $\mathrm{p}$-values found for individuals with sensorineural hearing loss were: waves $\mathrm{I}=0.343$, $\mathrm{III}=0.720, \mathrm{~V}=0.069$, interpeaks $\mathrm{I}-\mathrm{III}=0.289, \mathrm{III}-\mathrm{V}=0.120$ and $\mathrm{V}-\mathrm{I}=0.156$. 
TABLE 1. P-values calculated to compare BAEP responses by gender and ear in EG1.

\begin{tabular}{llllllll}
\hline & Waves and interpeak & I & III & V & I-III & III-V & I-V \\
\hline Ear & Wilcoxon & 0,817 & 0,152 & 0,522 & 0,282 & 0,640 & 0,646 \\
Gender & Mann-Witney U & 0,187 & $0,000^{*}$ & $0,000^{*}$ & $0,007 *$ & 0,276 & $0,001 *$ \\
\hline
\end{tabular}

Legend: * p- values considered statistically signific ant.

TABLE 2. Normal BAEP latency data in adults using the ND.

\begin{tabular}{llll}
\hline \multirow{2}{*}{ BAEP Components } & latency data & Mean +2,5 SD \\
\cline { 2 - 4 } & Mean (ms) & SD value & 1,87 \\
I & 1,50 & 0,15 & 4,02 \\
III & 3,57 & 0,18 & 6,05 \\
V & 5,53 & 0,21 & 2,53 \\
I-III & 2,06 & 0,19 & 2,43 \\
III-V & 1,96 & 0,21 & 4,49 \\
I-V & 4,02 & 0,21 & \\
\hline
\end{tabular}

Legend: SD = standard deviation.

TABLE 3. Mean values and their respective standard deviations of ab solute and in terpeak latencies of BAEP, with stimulation of 80 dBNAn, obtained from the literature and in the present study.

\begin{tabular}{|c|c|c|c|c|c|c|c|c|}
\hline Authors & Year of publication & & I & III & V & I-III & III-V & $\mathrm{I}-\mathrm{V}$ \\
\hline \multirow[t]{2}{*}{ Hall ${ }^{(1)}$} & 1992 & M & 1,54 & 3,73 & 5,52 & 2,19 & 1,79 & 3,98 \\
\hline & & SD & 0.08 & 0,10 & 0,15 & 0,18 & 0,25 & 0,23 \\
\hline \multirow[t]{2}{*}{ Munhoz et AL ${ }^{(14)}$} & 2000 & M & 1,54 & 3,7 & 5,6 & 2,2 & 1,84 & 4,04 \\
\hline & & SD & 0,10 & 0,15 & 0,19 & 0,16 & 0,17 & 0,18 \\
\hline \multirow[t]{2}{*}{ Anias et al ${ }^{(15)}$} & 2004 & M & 1,60 & 3,73 & 5,64 & 2,13 & 1,90 & 4,03 \\
\hline & & SD & 0,10 & 0,14 & 0,14 & 0,12 & 0,10 & 0,12 \\
\hline \multirow[t]{2}{*}{ Hall ${ }^{(10)}$} & 2006 & M & 1,65 & 3,8 & 5,64 & 2,15 & 1,84 & 3,99 \\
\hline & & SD & 0,14 & 0,18 & 0,23 & 0,14 & 0,14 & 0,20 \\
\hline \multirow[t]{2}{*}{ Lima et al ${ }^{(16)}$} & 2008 & M & 1,68 & 3,75 & 5,56 & 2,07 & 1,81 & 3,88 \\
\hline & & SD & 0,12 & 0,21 & 0,26 & 0,21 & 0,22 & 0,26 \\
\hline \multirow[t]{2}{*}{ Presente estudo } & 2009 & M & 1,50 & 3,57 & 5,53 & 2,06 & 1,96 & 4,02 \\
\hline & & SD & 0,15 & 0,18 & 0,21 & 0,19 & 0,21 & 0,21 \\
\hline
\end{tabular}

Legend: $\mathrm{M}$ = Mean; SD = Standard deviation.

\section{Discussion}

The BAEP latencies obtained in this study with the ND and those of the literature (table 3) showed minimal differences, that is, the mean latency for each wave and interpeak interval occurred within the variation of findings observed in the specialized literature articles consulted $(1,10,13)$.

Several authors report the importance of studying the normality pattern of BAEP. Although there is relative uniformity among different laboratories, absolute latencies and interpeak intervals may exhibit slight variations $(11,12,13,14,18,19)$.
The findings of this study showed that male latencies were higher than those of females, in accordance with the literature( $3,20,21,22)$.

Some authors report that the different BAEP latencies between men and women are a result of anatomical differences in anatomical differences between the sexes (auditory nerve diameter)(11,21).

The findings of this study underscore the similar responses for right and left ears, which is in accordance with the literature $(18,19,23)$, and showing the absence of statistical significance. Therefore, reference values can be used for both the right and left ear. 
The ND device demonstrated that wave V amplitude was higher than that of wave I. The wave $\mathrm{V}$ to wave I ratio is similar to that obtained in another study(24).

The findings of this study revealed that most individuals with sensorineural hearing loss had slight to moderate absolute latency values and normal interpeak intervals. These findings contrast with a study(25) that found a difference of $18 \%$ to $28 \%$ in abnormal BAEP results in patients with hearing loss between 40 and 59 dBNA at frequencies from 2000 to $4000 \mathrm{~Hz}$, in accordance with the literature $(4,26,27,28)$.

In severe to deep degrees of sensorineural hearing losses BAEP records are altered $(4,26,29,30)$. These degrees of hearing loss were not evaluated in this study.

BAEP latencies obtained using the ND and EP15 in the same individual were similar. Thus, electrophysiological records of latency for waves

\section{References}

1.Hall JW, New Handbook for Auditory Evoked Responses. Boston: Pearson Education. 1992. p.724-34.

2. Picton TW, Hillyard SA, Kraus HI, Galambos R. Human Arditory Evoked Potentials. I Evaluation of Components. Electroencephalorgraphy and Clinical Neurophisiology. 1974;36:179-90.

3. Hassan S, Dimitrov R, Munhoz MSL, Caovilla HH. Da influência do gênero, da intensidade do estímulo e do perímetro cefálico nas latências da Audiometria de Tronco Encefálico. Acta Awho. 1997;16(4):150-60.

4. Jewett DL, Williston JS. Auditory evoked far fields average from the scalp of humans. Brain. 1971;4:681-96.

5. Matas CG, Leite A, Gonçalves IC, Neves IF. Potenciais Evocados de Tronco Encefálico com Perdas Auditivas Condutivas e Neurossensoriais. Arquivos Internacionais de Otorrinolaringologia. 2005;9(4):1-7.

6. Menezes PL. Desenvolvimento de um dispositivo capaz de registrar e analisar potenciais evocados auditivos nos domínios do tempo e das frequências [tese]. São Paulo: Universidade de São Paulo; 2008.

7. Mallinson BR. Brainstem auditory evoked potentials in the assessment of hearing. S Afr Med J. 1986,69:813-16.

8. Hood L. The normal auditory brainstem response. In: Hood L. Clinical applications of the auditory brainstem response. San Diego: Singular; 1998. p. 126-44.

9. Tenório GA, Ferrite S, Teive P, Dultra A. Estimativa do diferencial entre os limiares auditivos subjetivos e eletrofisiológicos em adultos normo-uvintes. Arquivos Internacionais de Otorrinolaringologia. 2007;11(1):54-9.
I, III and V and interpeaks I-III, III-V and I-V were considered compatible with the gold standard device and can therefore be clinically used to perform BAEP.

\section{Conclusion}

The BAEP components measured with the new device in normal hearing adults were similar for both ears, while absolute latencies were lower in women than in men.

BAEP latencies in the same normal hearing individual or one with sensorineural hearing loss, as measured with the ND, were similar to those obtained with the Interacoustic EP15, the gold standard. In sensorineural hearing losses up to 60 dBNA, the most frequent BAEP finding was the presence of waves I, III and V, with normal absolute and interpeak latencies.

Normality reference values were obtained for BAEP in normal hearing adults.

10. Hall JW. New Handbook for Auditory Evoked Responses. Boston: Pearson Education. 2006. p. 212-57.

11. Rowe MJ. Normal Variability of the brain stem auditory evoked response in young and old adult subjects. Electroencephalography and Clinical Neurophysiology. 1978;44:459-70.

12. Stockard JJ. Stockard JE, Westmoreland B, Corfits J. Brainstem Auditory evoked response: normal variations as a function of stimulus and subject characteristics. Archives of Neurology. 1979;36:823-31.

13. Van Campen LE, Sammeth CA, May JW. Peek BF. Comparison of etymotic insert and TDH supra-aural earphones in auditory brainstem response measurement. J Am Acad Audiol. 1992;3(5):315-23.

14. Munhoz MSL, Silva MLG, Caovilla HH, Frazza MM, Ganança MG, Câmera JLZ. Respostas auditivas de tronco encefálico. In: Munhoz MSL, Caovilla HH, Silva MLG, Ganança MM. Audiologia clínica. São Paulo: Atheneu, 2000. p. 191-220.

15. Anias CR, Lima MAMT, Kós AOA. Avaliação da influência da idade no potencial evocado auditivo de tronco encefálico. Revista Brasileira de Otorrinolaringologia. 2004;70:84-9.

16. Lima JP de, Alvarenga KF, Foelkel TP, Monteiro CZ, Agostinho RS. Os efeitos da polaridade nos Potenciais Evocados Auditivos de Tronco Encefálico. Revista Brasileira de Otorrinolaringologia. 2008;74(5):725-30.

17. Sequeira MLC, Fukuda Y. Audiometria de tronco cerebral em indivíduos normais: estudo da latência das ondas. Acta awho. 1988; VII(1):29-37. 
18. Bento RF, Silveira JAM, Ferreira MRM, Fuess VLR, Miniti A. Estudo do padrão de normalidade da audiometria de tronco cerebral (BERA) nas diversas faixas etárias. Revista Brasileira de Otorrinolaringologia. 1998;54:37-41.

19. Esteves MCBN, Aringa AHBD, Arruda GV, Aringa ARD, Nardi JC. Estudo das latências das ondas dos potenciais auditivos de tronco encefálico em indivíduos ouvintes normais. Jornal Brasileiro de Otorrinolaringologia. 2009;75(3):420-5

20. Hecox K, Squires N, Galambos R. - Brainstem auditory evoked responses in man. I. Effect of stimulus rise-fall time and duration. J. Acoust. Soc. Am. 1976;60:1187-92.

21. Jeger J, Hall J. Effects of age and sex on Auditory Brainstem Response. Arch Otolatyngol. 1980;106(7):38791.

22. Macedo JCF, Suzuki FA, Felipe RG, Fukuda Y. Audiometria de Tronco Cerebral em indivíduos normais acima de 50 anos. Estudo do tempo de latência comparativo entre os gêneros. Pró-Fono. 1990;2(2):21-2.

23. Musiek FE, Kibbe K, Rackliffe L, Weider DJ. The auditory brain stem response I-V amplitude ratio in normal, cochlear, and retrocochlear ears. Ear Hear. 1984 JanFeb;5(1):52-5.

24. Bauch CD, Olsen WO. Auditory Brainstem Response as a Function of Average Hearing Sensitivity for $2000-4000 \mathrm{~Hz}$. Audiology. 1988;27(3):156-63.
25. Watson DR. A study of the effects of coclear loss on the auditory brainstem response (ABR) specificity and false positive rate in retrococlear assessment. Audiology. 1999; 38(3):155-64.

26. Gorga MP, Reiland JK, Beauchaine KA. Auditory brainstem response in a case of high-freqüency conductive hearing loss. J Speech Hear Disord. 1985;50:346-50.

27. Gorga MP, Beauchaine KA, Reiland JK, Worthington DW, Javel E. - The effects of stimulus duration on ABR and behavioral thresholds. J. Acoust. Soc. Am., 1984;76(2): 616-19.

28. Gorga MP, Johnson TA, Kaminski JR, Beauchaine KL, Garner CA, Neely ST. Using a combination of click- and tone burst-evoked auditory brain stem response measurements to estimate pure-tone thresholds. Ear Hear 2006; 27(1):p.60-74.

29. Boettcher FA. Presbiacusis and auditory brainstem response. J Speech Lang Hear Res Rockville. 2002;45(6):1249-61.

30. Harkins SW, Lenhardt ML. Effects of age and interstimulus interval on brainstem auditory evoked potential. Intern J Neuroscience. 1981;15:107-18. 